\title{
Prognostic Importance of Thrombocyte Indices in Children with Carbon Monoxide Poisoning
}

\section{Çocuklarda Karbonmonoksit Zehirlenmelerinde Trombosit Indekslerinin Prognostik Önemi}

Fatih Akin ${ }^{1}$

Alaaddin Yorulmaz ${ }^{2}$

Abdullah Yazar ${ }^{1}$

Esra Ture ${ }^{1}$

Esma Erdemir ${ }^{3}$

Birsen Ertekin ${ }^{3}$

Tarik Acar $^{3}$

${ }^{1}$ Necmettin Erbakan University, Meram Faculty of Medicine, Department of Pediatrics, Konya, Turkey

${ }^{2}$ Selcuk University, Selcuklu Faculty of Medicine, Department of Pediatrics, Konya, Turkey

${ }^{3}$ Beyhekim State Hospital, Department of Emergency, Konya, Turkey

Geliş Tarihi/Received: 11 July 2018 Kabul Tarihi/Accepted: 20 December 2018

Address correspondence to: Fatih Akin, Necmettin Erbakan University, Meram Faculty of Medicine, Department of Pediatric Emergency, Konya, Turkey, 42080, MeramKonya, Turkey

e-mail: drfatihakin@gmail.com

\section{ORCID}

Fatih Akin

https://orcid.org/0000-0001-5725-3867

\begin{abstract}
$\ddot{O} z$
Amaç: Karbonmonoksit zehirlenmesi, tüm dünyada hala önemli bir morbidite ve mortalite nedenidir. Trombosit fonksiyonlarının karbonmonoksit zehirlenmesindeki rolü net olmamakla birlikte, trombosit aktivasyon ve agregasyonunun arttığı bildirilmiştir. Karbonmonoksit zehirlenmesinde, endotel hasarına bağlı artan trombotik eğilim, artmış trombosit yapışması ve fibrinolitik yoldadeğişiklikler ortaya çıkar. Çalışmamızın amacı trombosit indekslerinin karbonmonoksit zehirlenmesi olan çocuklarda klinik yarar sağlayıp sağlamadığını belirlemektir.

Hastalar ve Yöntem: Necmettin Erbakan Üniversitesi Meram Tıp Fakültesi ve Konya Beyhekim Devlet Hastanesi Çocuk Acil Servislerine başvuran karbonmonoksit zehirlenmesi tanılı çocukların kayıtlarını retrospektif olarak gözden geçirdik. Çalışmaya karbonmonoksit zehirlenmesi olan 92 çocuk ve 62 yaş ve cinsiyet uyumlu sağlıklı kontrol dahil edildi.

Bulgular: CO zehirlenmesi olan hastalarda ortalama trombosit hacmi ve trombosit dağılım genişliği düzeyleri anlamlı olarak yüksek iken $(9,34 \pm 0,55$ vs $9,78 \pm 0,97 \mathrm{fL}, p=0,001 ; 11,46 \pm 2,64$ vs 10,57$) \pm$ $1,41$, sırasıyla, $p=0.007)$, trombosit sayısı ve plateletrit $(324,05 \pm 82,07$ vs 357,27 $\pm 89,70 \times 109 p=0,015$ $0,31 \pm 0,06$ vs $0,33 \pm 0,07$, sırasıyla, $p=0.039$ ) anlamlı olarak daha düşüktü. Ortalama trombosit hacmi seviyeleri ise karboksi hemoglobin düzeyi 20 'den yüksek olan hastalarda, karboksi hemoglobin seviyeleri 20-20 arasında olanlara göre anlamlı olarak daha yüksekti $(9,40 \pm 0,84$ vs $10,08 \pm 1,22 \mathrm{fL}, \mathrm{p}=0.003)$

Sonuç: Sonuçlarımız karbonmonoksit zehirlenmesi olan hastalarda trombosit indekslerinden ortalama trombosit hacmi ve trombosit dağılım genişliğinin belirgin şekilde yükseldiğini trombosit sayısı ve plateletritin azaldığını gösterdi. Trombosit aktivasyonu ve fonksiyonundaki değişiklikleri yansıtan ortalama trombosit hacmi ve trombosit dağılım genişliği düzeyleri, karbonmonoksit zehirlenmesi sırasında özellikle tromboembolik komplikasyonların gelişimini öngörebilir. Ortalama trombosit hacmi ve trombosit dağılım genişliği düzeyleri karbonmonoksit zehirlenmesinin prognostik tahmininde yararlı olabilir
\end{abstract}

Anahtar Kelimeler: Çocuk, karbonmonoksit, trombosit indeksleri, zehirlenme

\section{Abstract}

Aim: Carbon monoxide (CO) poisoning is still being a major cause of morbidity and mortality all over the world. Although the role of platelet functions in $\mathrm{CO}$ poisoning is not clear, increased platelet activation and aggregation had been reported previously. Increased thrombotic tendency due to endothelial damage, increased platelet stickiness, and alterations in the fibrinolytic pathway occurs in CO poisoning. The aim of our study was to determine whether platelet indices provide clinical benefit or not in children with $\mathrm{CO}$ poisoning.

Patients and Methods: We retrospectively reviwed the records of children with the diagnosis of $\mathrm{CO}$ poisoning who admitted to the pediatric emergency departments of Konya Beyhekim State Hospital and Necmettin Erbakan University Meram Medical Faculty. A total of 92 children with CO poisoning and 62 age- and gender-matched healthy controls were included in the study

Results: While mean platelet volume (MPV) and platelet distribution width (PDW) levels were significantly higher $(9,34 \pm 0,55$ vs $9,78 \pm 0,97 \mathrm{fL}, p=0.001 ; 11,46 \pm 2,64$ vs $10,57 \pm 1,41$, retrospectively, $p=0.007)$, platelet count and plateletcrit (PCT) $(324,05 \pm 82,07$ vs $357,27 \pm 89,70 \times 109 p=0.015 ; 0,31 \pm 0,06$ vs $0,33 \pm 0,07$ retrospectively, $p=0.039$ ) were significantly lower in patients with CO poisoning. MPV levels were also significantly higher in patients with a carboxy hemoglobin $(\mathrm{COHb})$ level higher than 20 , when compared

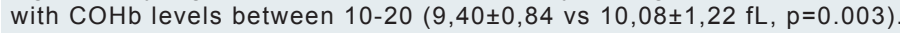

Conclusion: Our results showed that platelet indices MPV and PDW are markedly elevated in patients with CO poisoning while platelet count and PCT were decreased. MPV and PDW levels, which reflect the changes in platelet activation and function, may predict the development of especially thromboembolic complications in the course of CO poisoning. MPV and PDW levels may be useful in prognostic estimation of $\mathrm{CO}$ poisoning.

Key words: Children, carbon monoxide, platelet indices, poisoning

\section{INTRODUCTION}

Carbon monoxide (CO) poisoning is still a major cause of morbidity and mortality across the world. In the United States, it is the second most frequent poisoning listed on death certificates (1). It is the most common cause of poisoning resulting with death in our country (2).

$\mathrm{CO}$ is a toxic but non-irritating gas because it is colorless, tasteless and odorless. It is produced during the combustion of any carbon containing fuel (3). Affinity of CO to hemoglobin is more than 200300 times of oxygen. The capture of hemoglobin
Cite this article as: Akin F, Yorulmaz A, Yazar A, Ture E, Erdemir E, Ertekin E, Acar A. Prognostic Importance of Thrombocyte Indices in Children with Carbon Monoxide Poisoning. Selcuk Med J 2019;35(3): 180-187
Disclosure: None of the authors has a financial interest in any of the
products, devices, or drugs mentioned in this article. The research was
not sponsored by an outside organization. All authors have agreed to allow
full access to the primary data and to allow the journal to review the data
if requested. 
molecule by $\mathrm{CO}$ results with reduced oxygen delivery to tissues, hypoxia, direct cell damage and lactic acidosis. $(3,4)$. Although hypoxia due to hemoglobin effects of $\mathrm{CO}$ was thought to be the major cause of most of the morbidity and mortality from $\mathrm{CO}$ poisoning, extra-hemoglobin effects including nitric oxide (NO) release, generation of reactive oxygen species and direct activity on ion channels especially in the heart and the brain are suggested as more important factors in recent studies (5). CO poisoning affects children more quickly. Due to tissue hypoxia and direct cellular damage, non-specific clinical findings or serious consequences ranging from mental status changes to death may be encountered (1). Symptoms may include nausea, vomiting, malaise, headache, dizziness, muscle cramps, abdominal pain, dyspnea, confusion and ataxia. Central nervous system and cardiological system involvement may cause serious consequences $(3,6)$.

Thrombocytes are non-nucleated small fragments 1-2 $\mu \mathrm{m}$ in size with a life span of 8-10 days and derived from megakaryocytes in the bone marrow (7). Platelets play role in various processes in the body, including hemostasis, inflammation, immune cell activation, tissue regeneration (8). Young thrombocytes derived from the bone marrow due to inflammation are larger in size. Cytokines, chemokines, and procoagulant molecules are secreted by inflammation activated platelets. Mean platelet volume (MPV), platelet distribution width (PDW) and plateletcrit (PCT) are platelet indices. MPV, is a frequently used parameter to assess platelet activation and function, because it shows the rate of bone marrow platelet production and size $(9,10)$. PDW is an indicator of the difference in platelet volume and the degree of variation of platelet size. It reflects the changes in platelet activation and function (11).

The importance of platelet indices in $\mathrm{CO}$ poisoning has not been clarified completely. CO exposure results with the release of $\mathrm{NO}$, which is secreted mainly from hemeproteins in platelets (5). MPV is elevated in cerebrovascular and cardiovascular diseases (7). Because cerebrovascular and cardiac effects of $\mathrm{CO}$ are considered to be the most important factors affecting the prognosis, we hypothesized that detailed evaluation of platelet indices in the course of CO poisoning would be of utility for clinical practice. Thus we decided to compare platelet indices of patients with $\mathrm{CO}$ poisoning with a healthy control group. We also planned to compare platelet indices of patients exposed to $\mathrm{CO}$ with different severity, to ensure whether platelet indices showed significant differences at different degree of poisoning. MPV was found to be increased in a study which was conducted on adults with CO poisoning (12). The aim of our study was to determine whether platelet indices provide clinical benefit or not in children with CO poisoning.

\section{PATIENTS AND METHODS}

Electronic medical records of 0-16 years old patients with $\mathrm{CO}$ poisoning who admitted to the pediatric emergency departments of two hospitals of our city between January 2015 and December 2016 were reviewed retrospectively by two physicians who were blinded to the purpose of the study. The diagnosis of $\mathrm{CO}$ poisoning was based on anamnesis and the level of carboxyhemoglobin $(\mathrm{COHb})$ which was above 5\%. Parameters including age, gender, season, time of admission, symptoms and findings on admission, source of $\mathrm{CO}$ gas, results of laboratory analysis which were complete blood count, aspartate aminotransaferase (AST) (IU/L), alanine aminotransaferase (ALT) (IU/L), urea $(\mathrm{mg} /$ $\mathrm{dl})$, creatinin $(\mathrm{mg} / \mathrm{dl})$, sodium $(\mathrm{mEq} / \mathrm{L})$, potassium $(\mathrm{mEq} / \mathrm{L})$, calcium $(\mathrm{mg} / \mathrm{dl})$, lactate levels $(\mathrm{mmol} / \mathrm{L})$ and blood gas analysis including $\mathrm{COHb}(\%), \mathrm{pH}, \mathrm{pCO} 2$ $(\mathrm{mmHg}), \mathrm{pO} 2(\mathrm{mmHg}), \mathrm{HCO} 3(\mathrm{mmol} / \mathrm{L})$ were collected by using the computerized patient databases of the two hospitals. Data were also abstracted by the same physicians.

Exclusion criteria were determined as any history of hematological disease, neurological disease, liver disease, chronic renal disease, diabetes mellitus, heart disease, autoimmune disease, malignancy, any inflammatory disease, and taking of antiplatelet or anticoagulant therapy. Additionally, because laboratory results of patients who were referred for hyperbaric oxygen treatment were not available, they could not be included into the study. Seventy-two age and sex-matched outpatient healthy children, who did not have any chronic illness or sign of infection with normal physical examination findings, and undergoing blood analyses for other reasons (i.e. routine checkup, suspicion of anemia, loss of appetite, abdominal pain) constituted the control group. Children with any abnormal laboratory result were not enrolled into the control group.

When patients applied to the emergency unit, $100 \%$ oxygen therapy (normobaric oxygen therapy) was given with non-rebreathing mask with an oxygen reservoir bag. While, decreased $\mathrm{COHb}$ levels below 
$5 \%$ and improvement of symptoms were defined as healing criteria, duration of treatment was defined as the time period of receiving supplemental oxygen. Patients with loss of consciousness and/or coma were sent to another center where hyperbaric oxygen (HBO) treatment was available. Patients were divided into three groups according to $\mathrm{COHb}$ levels: Group 1 (5-10\%) (mild poisoning), group 2 (10-20\%) (moderate poisoning), group 3 (>20\%) (severe poisoning).

\section{Statistical analysis}

Statistical methods of descriptive data were shown as mean \pm standard deviation. Kolmogorov-Smirnov normality test was applied to check the distribution of parameters. While parametric data were analyzed using student's t-test, nonparametric were analyzed with chi-square test. One-way Anova test was used for multiple comparisons, and Tukey's HSD test was used for post hoc analysis. Pearson correlation test was applied for the correlation analysis of the parameters. $p<0.05$ was considered as statistically significant. IBM SPSS 24.0 (SPSS Inc, Chicago, Illinois, United States of America) packet computer program was used for statistical analysis.

\section{RESULTS}

107832 patients had admitted to pediatric emergency department during this period and 128 patients were found to have the diagnosis of $\mathrm{CO}$ poisoning. While 36 of them were excluded due to exclusion criterias, the study group was consisted of 92 patients (47 male, 45 female; mean age $96 \pm 52$ months). While 16 patients were excluded due to

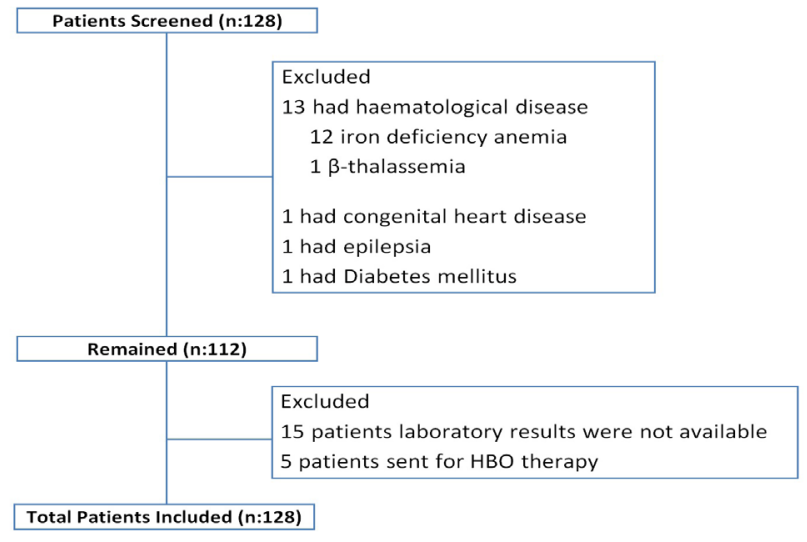

Figure 1. Exclusion criteria and patient selection diagram
Table 1. Demographic characteristics of patients with $\mathrm{CO}$ poisoning and the control group

\begin{tabular}{lll}
\hline \multicolumn{1}{c}{ Patients Control Group } & \\
Number of Participants & & \\
\hline$(\mathrm{n}(\%))$ & $92(100)$ & $72(100)$ \\
Gender $(\mathrm{n}(\%))$ & $47(51.1)$ & $37(51.4)$ \\
$\quad$ Male & $45(48.9)$ & $35(48.6)$ \\
$\quad$ Female & $96 \pm 52$ & $90 \pm 51$ \\
Mean Age (month) & \\
Seasonal Distribution ( $(\%))$ & \\
$\quad$ Winter & $27(50.0)$ & \\
$\quad$ Spring & $19(29.3)$ & \\
$\quad$ Autumn & & \\
CO Source (n(\%)) & \\
$\quad$ Stove & $66(93.47)$ \\
$\quad$ Water Heater & $5.50 \pm 2.80$ & \\
Duration of Treatment* (hour) & \\
*the total time period of oxygen treatment
\end{tabular}

${ }^{*}$ the total time period of oxygen treatment

various diseases, 15 patients' laboratory results of were not available and 5 patients had been sent for HBO therapy because of loss of consciousness and coma (Figure 1). The characteristics of the patients are shown in table 1. The most frequent recorded symptoms at the time of admission were weakness $(80.4 \%)$, nausea (76.1\%), headache (62.0\%), dizziness (39.1\%) and vomiting (17.4\%) (Table 2). CO source was stove in $93.47 \%(n: 86)$ of the patients and water heater in $6.53 \%$ ( $\mathrm{n}: 6)$.

The time of admittance of the patients to pediatric emergency clinics were as follows; 45 (48.9\%) between 08.00-16.00, 37 (40.2\%) between 24.0008.00 and 10 (10.9\%) between 16.00 and 24.00 hours. It was seen that the patients were brought to the emergency service most frequently at 09:00 o'clock. The time of the admittance of the patients are shown in figure 2 . When the distribution of patients

Table 2. Recorded symptoms of patients on admission

\begin{tabular}{ll}
\hline Symptom & $\mathbf{n}(\%)^{*}$ \\
\hline Weakness & $74(80.4)$ \\
Nausea & $70(76.1)$ \\
Headache & $57(62.0)$ \\
Dizziness & $36(39.1)$ \\
Vomiting & $16(17.4)$ \\
Slope to sleep & $7(7.6)$ \\
Tachycardia & $5(5.4)$ \\
Dyspnea & $3(3.3)$ \\
Loss of consciousness & $1(1.1)$ \\
Chest pain & $1(1.1)$ \\
Abdominal pain & $1(1.1)$ \\
\hline
\end{tabular}

*Patients had more than one symptom and that is why the percentages add toover $100 \%$. 


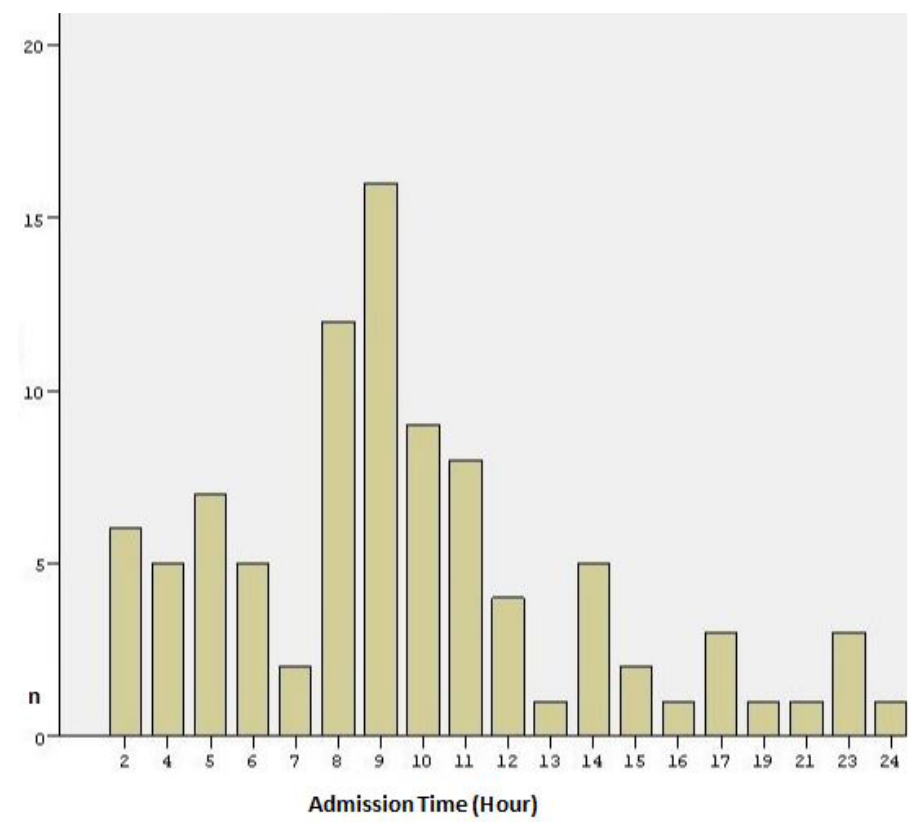

Figure 2. The distribution of admission hours of patients with $\mathrm{CO}$ poisoning

were evaluated by month, the highest rate of $\mathrm{CO}$ poisoning was in January which was $26.1 \%(n=24)$. This was followed by March with the rate of $18.5 \%$ ( $\mathrm{n}$ : 17) (Figure 3). Seasonal distribution showed that $\mathrm{CO}$

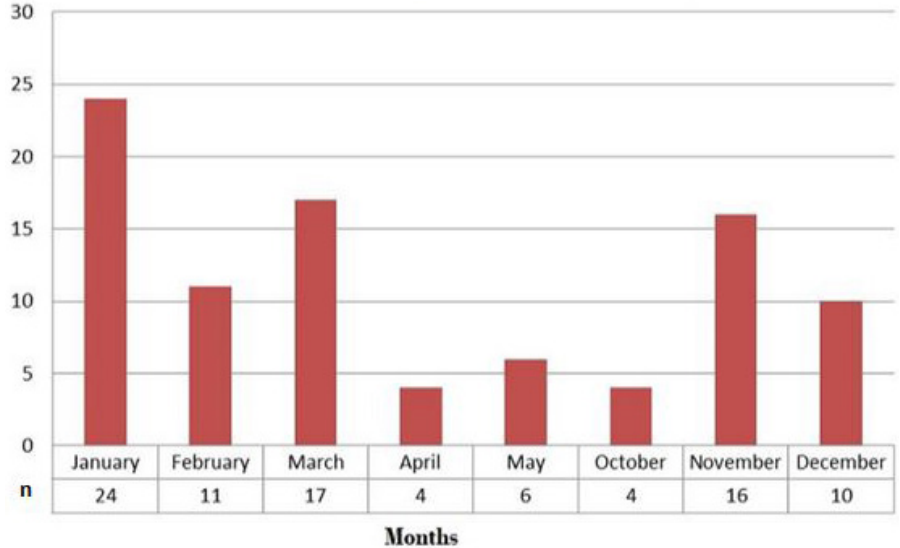

Figure 3. Monthly distribution of patients with $\mathrm{CO}$ poisoning

poisoning was seen mostly in winter $(50 \%(n=46))$, as expected (Table 1).

There was no statistically significant difference between the study group and the control group when laboratory results including hemoglobine $(\mathrm{Hb})$, mean corpuscular volume (MCV), red cel distribution width (RDW), urea, sodium, potassium, AST and ALT were compared. However, white blood cell count (WBC), hematocrit, absolute neutrophil count (ANC), absolute

Table 3. Comparison of the laboratory results of patients and the controls

\begin{tabular}{|c|c|c|c|}
\hline & Patients & Controls & p value \\
\hline$\overline{\mathrm{WBC}\left(\text { count } / \mathrm{mm}^{3}\right)}$ & $10.03 \pm 3.58$ & $9.01 \pm 2.42$ & 0.032 \\
\hline Hemoglobin (g/dl) & $12.51 \pm 1.77$ & $12.93 \pm 1.15$ & 0.082 \\
\hline Hematocrit (\%) & $37.26 \pm 3.45$ & $38.92 \pm 3.04$ & 0.002 \\
\hline $\mathrm{MCV}(\mathrm{fL})$ & $76.67 \pm 6.93$ & $80.18 \pm 29.34$ & 0.269 \\
\hline RDW (\%) & $13.95 \pm 1.45$ & $14.78 \pm 7.65$ & 0.310 \\
\hline ANC (count $\left./ \mathrm{mm}^{3}\right)$ & $5.98 \pm 3.30$ & $3.62 \pm 1.58$ & 0.001 \\
\hline ALC (count $\left./ \mathrm{mm}^{3}\right)$ & $3.23 \pm 1.95$ & $4.39 \pm 1.59$ & 0.001 \\
\hline NLR & $2.85 \pm 2.73$ & $0.94 \pm 0.60$ & 0.001 \\
\hline Platelet counts (count $\times 10^{3} / \mathrm{mm}^{3}$ ) & $324.05 \pm 82.07$ & $357.27 \pm 89.70$ & 0.015 \\
\hline MPV (fL) & $9.78 \pm 0.97$ & $9.34 \pm 0.55$ & 0.001 \\
\hline PDW (\%) & $11.46 \pm 2.64$ & $10.57 \pm 1.41$ & 0.007 \\
\hline РCT $(\%)$ & $0.31 \pm 0.06$ & $0.33 \pm 0.07$ & 0.039 \\
\hline Urea $(\mathrm{mg} / \mathrm{dl})$ & $24.19 \pm 6.78$ & $23.67 \pm 6.96$ & 0.641 \\
\hline Creatinine (mg/dl) & $0.49 \pm 0.11$ & $0.41 \pm 0.12$ & 0.001 \\
\hline Sodium $(\mathrm{mEq} / \mathrm{L})$ & $135.68 \pm 13.76$ & $138.07 \pm 2.77$ & 0.195 \\
\hline Potassium (mEq/L) & $4.77 \pm 3.88$ & $4.39 \pm 0.35$ & 0.460 \\
\hline AST (IU/L) & $27.35 \pm 9.74$ & $28.05 \pm 8.17$ & 0.646 \\
\hline ALT (IU/L) & $14.26 \pm 7.46$ & $14.94 \pm 4.45$ & 0.528 \\
\hline Calcium (mg/dl) & $9.66 \pm 0.43$ & $9.89 \pm 0.47$ & 0.014 \\
\hline $\mathrm{COHb}(\%)$ & $15.60 \pm 8.62,14(5-35)^{*}$ & & \\
\hline Lactate $(\mathrm{mmol} / \mathrm{L})$ & $2.46 \pm 1.48$ & & \\
\hline $\mathrm{pH}$ & $7.37 \pm 0.04$ & & \\
\hline
\end{tabular}


Table 4. Comparison of laboratory parameters of patients with $\mathrm{CO}$ poisoning according to $\mathrm{COHb}$ levels

\begin{tabular}{|c|c|c|c|c|}
\hline COHb levels (\%) & $5-10$ & $10-20$ & $>20$ & p values \\
\hline $\mathrm{n}$ & 31 & 31 & 30 & \\
\hline $\mathrm{pH}$ & $7.38 \pm 0.03$ & $7.37 \pm 0.03$ & $7.35 \pm 0.04^{*}$ & 0.017 \\
\hline Lactate $(\mathrm{mmol} / \mathrm{L})$ & $1.57 \pm 0.70^{*}$ & $2.67 \pm 1.03$ & $3.21 \pm 1.96$ & 0.001 \\
\hline Platelet count (count $\left.\times 10^{3} / \mathrm{mm}^{3}\right)$ & $322.90 \pm 57.90$ & $348.03 \pm 88.85$ & $301.30 \pm 92.34$ & 0.072 \\
\hline$M P V(f L)$ & $9.82 \pm 0.70$ & $9.45 \pm 0.87^{* *}$ & $10.08 \pm 1.22^{* *}$ & 0.043 \\
\hline PDW (\%) & $11.05 \pm 1.43$ & $11.27 \pm 2.76$ & $12.08 \pm 3.35$ & 0.285 \\
\hline PCT $(\%)$ & $0.31 \pm 0.06$ & $0.32 \pm 0.07$ & $0.29 \pm 0.06$ & 0.140 \\
\hline \multicolumn{5}{|l|}{ WBC } \\
\hline (count $\times 10^{3} / \mathrm{mm}^{3}$ ) & $10.12 \pm 3.23$ & $11.13 \pm 4.33^{* *}$ & $8.79 \pm 2.65^{\star *}$ & 0.036 \\
\hline ANC (count $\left.\times 10^{3} / \mathrm{mm}^{3}\right)$ & $5.94 \pm 3.56$ & $7.03 \pm 3.64^{* *}$ & $4.93 \pm 2.23^{* *}$ & 0.043 \\
\hline Creatinine (mg/dl) & $0.45 \pm 0.11$ & $0.47 \pm 0.11$ & $0.55 \pm 0.10^{*}$ & 0.004 \\
\hline AST (IU/L) & $30.49 \pm 12.27$ & $27.13 \pm 7.82$ & $24.11 \pm 7.42^{*}$ & 0.040 \\
\hline
\end{tabular}

Parametric values were expressed as means \pm standard deviation. Significance was determined by $p<0.05$. AST aspartate aminotransaferase COHb carboxyhemoglobin, MPV mean platelet volume, PCT plateletcrit, PDW platelet distribution width, WBC White blood cell, ANC absolute neutrophil count,

* the group showing significant difference from others, ${ }^{* *}$ the two groups showing statistically significant difference from each other.

lymphocyte count (ALC), neutrophil-to-lymphocyte ratio (NLR), creatinine and calcium levels showed statistically significant difference which were higher in patients with $\mathrm{CO}$ poisoning. Statistically significant differences were also detected between the patient group and control group when platelet index parameters including platelet count, MPV, platelet distribution width (PDW) and plateletcrit (PCT) were compared (Table 3). Patients with $\mathrm{CO}$ poisoning who were classified into three groups according to levels of $\mathrm{COHb}$ were compared. $\mathrm{pH}$ levels were significantly lower in group 1 when compared with group 3 . Lactate levels were significantly lower in group 1 from both other groups. There was statistically significant difference between groups 2 and 3 in terms of MPV, ANC and WBC levels. There was no significant difference between groups in terms of PDW and PCT. Detailed results are given in table 4. Evaluation of symptoms of the patient groups according to $\mathrm{COHb}$ revealed that patients with vomiting and slope to sleep were all in group 3 (COHb levels $>20 \%)$ $(k 2=40.02, p<0.001 ; k 2=15.65, p<0.001)$. While the absence of headache was significantly associated with low levels $(5-10 \%)$ of $\mathrm{COHb}(\mathrm{k} 2=21.69, \mathrm{p}<0.001)$, dizziness was associated with high levels (>20\%) of $\mathrm{COHb}(\mathrm{k} 2=23.92, \mathrm{p}<0.001) .80 \%$ of the patients with tachicardia had significantly high levels of $\mathrm{COHb}$

Table 5. Correlation of platelet count with platelet indices

\begin{tabular}{llll}
\hline & MPV (fI) & PDW (\%) & PCT (\%) \\
\hline Platelet count & & & \\
$\left(\right.$ count $\left.10^{3} / \mathrm{mm}^{3}\right)$ & p:0.001 & $r:-0.44$ & 0.001 \\
& -0.34 & 0.000 & 0.75 \\
\hline
\end{tabular}

$(k 2=5.71, p=0.004)$.

A negative correlation was found between MPV and platelet count ( $\mathrm{p}: 0.001, \mathrm{r}:-0.44)$. There was a strong correlation between MPV and PDW (p: 0.001, $r: 0.705)$. A strong correlation was also found between platelet count and PCT (p: 0.001, r: 0.75). COHb and lactate levels showed no correlation with platelet indices. These two parameters showed correlation with the occurrence of the signs and symptoms including headache, nausea, vomiting, dizziness, and tachycardia on admittance. The mean duration of hospitalization was $5,50 \pm 2,80$ hours. A strong correlation was found between the mean $\mathrm{COHb}$ level and the duration of treatment ( $p: 0.001, r: 0.889)$. Lactate levels also showed a correlation with the duration of treatment (p: 0.001, r: 0.507).

Complete blood count results of the patients sent for HBO therapy were not available in the computerized patient database. 1 patient with loss of consciousness could not be sent to the center where HBO was available because of familal reasons. $\mathrm{COHb}$ level of this patient was $35 \%$ and he improved immediately after starting oxygen therapy.

\section{DISCUSSION}

We found significant elevations in MPV and PDW levels in patients with $\mathrm{CO}$ poisoning when compared to the control group. Additionally platelet count and PCT levels were lower. MPV, which is frequently used as a parameter to evaluate platelet activation and function, reflects the platelet size and rate of platelet production in the bone marrow $(9,10)$. Larger thrombocytes contain more granules, release more thromboxane A2 and bind more rapidly with collagen 
(13-15). Karabacak et al. (12) reported that MPV levels were significantly higher in patients with $\mathrm{CO}$ poisoning $(8.9 \pm 0.8$ vs $7.9 \pm 0.9 \mathrm{fL}$, respectively; $\mathrm{P}<$ .001) when compared with the control group. MPV has been shown to be increased at hypoxic environments such as high altitude settlements above sea level suggesting that hypoxia in patients with $\mathrm{CO}$ poisoning may cause an increase in MPV levels directly (16). The MPV values had also increased significantly in patients with $\mathrm{CO}$ poisoning when compared to controls in our study. We observed highest levels of MPV in patients with higher $\mathrm{COHb}$ levels. These findings suggest that $\mathrm{CO}$ poisoning causes an increase in MPV levels. In addition to hypoxia, increased activation of platelets may contribute the complications seen in CO poisoning.

The concentration of $\mathrm{CO}$ in atmosphere is under $0.001 \%$. Exposure to CO results with left shift in the oxygen-hemoglobin dissociation curve, reduced oxygen delivery, and subsequent tissue hypoxia $(3,4,17)$. In addition to this hemoglobin effect, $\mathrm{CO}$ also has extra-hemoglobin effects. It has been reported that $\mathrm{CO}$ by itself is toxic to human mitochondria and affects the mitochondrial respiratory chain at cytochrome c oxidase level (18). In a study conducted on dogs, dogs were transfused with red cells containing $80 \% \mathrm{COHb}$ and they all survived. This suggested that a high carboxyhemoglobin level does not mean a patient has poisoning of their cytochrome oxidase system and direct effects of free $\mathrm{CO}$ on this system is also an important mechanism of toxicity (19). Mitochondrial electron transport degrades in the course of $\mathrm{CO}$ poisoning due both high $\mathrm{COHb}$ levels and direct effects of $\mathrm{CO}$ binding to cytochrome c oxidase. ATP synthesis decreases and reactive oxygen species increase in the affected tissue $(20,21)$. Although mitochondrial function recover after $\mathrm{COHb}$ levels come to normal range, neuronal death may occur in this period in the brain $(22,23)$. These processes may explain the neurologic symptoms that develope in patients with $\mathrm{CO}$ poisoning.

Although the role of platelets in $\mathrm{CO}$ poisoning is unclear, increased platelet activation and aggregation had been reported previously $(24,25)$. CO poisoning induce thrombotic propencity due to endothelial damage and changes in the fibrinolytic pathway $(26,27)$. These processes had been suggested to constitute the background of myocardial infarction seen in the course of CO poisoning $(28,29)$. There are few studies that directly investigate platelet function in acute $\mathrm{CO}$ poisoning. $\mathrm{CO}$ poisoning, extra-hemoglobin effects including nitric oxide (NO) release, generation of reactive oxygen species and direct activity on ion channels especially in the heart and the brain are suggested as more important factors in recent studies (5). CO poisoning activates the release of nitric oxide and generation of free oxygen radicals. The increase of platelet aggregation platelet adhesion due to free oxygen radicals contribute to endothelial damage (30-32). Myocardial ischemia and myocardial infarction due to $\mathrm{CO}$ poisoning even in the absence of any underyling coronary artery disease have been showed in previous studies (32-35).

PDW is another indicator of platelet function. It shows the degree of diversity of platelet volume and size (11). The reason for their use as marker is that pseudopod formations occur due to platelet activation which causes changes in platelet morphology. PDW increases due to increased young platelets as a response of bone marrow in thrombocytopenic patients. Increased PDW also exhibits anisocytosis, which may be associated with pseudopod formation. PDW is more indicative than MPV to show platelet activation in the activation process (36). There are some studies in the literature about the relationship of PDW and various diseases but not with $\mathrm{CO}$ poisoning. In our study, we found that mean PDW levels were statistically higher in patients with $\mathrm{CO}$ poisoning than the control group. PCT may be useful in diseases where platelet count is low but the diameter is large. Because even though the number platelets is low, platelet functions can be maintained by large thrombocytes and PCT may be more useful in these patients. PCT was found to be less than $1 \%$ in patients undergoing transfusion due to bleeding after cardiopulmonary bypass. This shows that PCT is as important as platelet count in thrombocytopenic patients (37). It is known that there is a significant relationship between platelet count and PCT. These findings suggest that platelet count and PCT are two important factors for hemostasis (38). In our study, PCT levels were significantly lower in patients with $\mathrm{CO}$ poisoning than those in the control group. Additionally a negative correlation was found between MPV and platelet count in our study. This may be attributed to production of larger thrombocytes from bone marrow in conditions with lower platelet count.

This study had some limitations. The retrospective design was the first limitation. Secondly this was a two centred study and the physicians who abstracted the datas were not the same person. Thirdly, the laboratory results of some patients were not available. 
Lastly, patients needing HBO therapy could not be included to the study because they were directly referred to the hospital where HBO therapy was available.

In conclusion, our results showed that platelet indices MPV and PDW are markedly elevated in patients with $\mathrm{CO}$ poisoning while platelet count and PCT were decreased. MPV and PDW levels, which reflect the changes in platelet activation and function, may predict the development of especially thromboembolic complications in the course of CO poisoning. MPV and PDW levels may be useful in prognostic estimation of $\mathrm{CO}$ poisoning. More comprehensive studies are needed in especially complication developed and $\mathrm{HBO}$ treated patients to clarify this issue.

Conflict of interest: Authors declare that there is no conflict of interest between the authors of the article.

Financial conflict of interest: Authors declare that they did not receive any financial support in this study.

Address correspondence to: Fatih Akin, Necmettin Erbakan University, Meram Faculty of Medicine, Department of Pediatric Emergency, Konya, Turkey, 42080, MeramKonya, Turkey

E-mail:drfatihakin@gmail.com

\section{REFERENCES}

1. Sircar K, Clower J, Shin MK, et al. Carbon monoxide poisoning deaths in the United States, 1999 to 2012. Am J Emerg Med 2015;33(9):1140-5.

2. Uysal C, Celik S, Duzgun AA, et al. Carbon monoxide-related deaths in Ankara between 2001 and 2011. Inhal Toxicol 2013;25(2):102-6.

3. Kostic MA. Nelson textbook of pediatrics. In: Kliegman RM, Stanton BF, Geme JW, Schor NF, eds. Poisoning. Philadelphia: Elsevier, 2016: 447-67.

4. Camurdan DA, Beyazova U. Çocukluk çağı zehirlenmelerinde değerlendirme ve genel tedavi yaklaşımları. Turkiye Klinikleri J Pediatr 2006; 2:5-10.

5. Roderique JD, Josef CS, Feldman MJ, et al. A modern literature review of carbon monoxide poisoning theories, therapies, and potential targets for therapy advancement. Toxicology 2015;334:45-58.

6. Gozubuyuk AA, Dag H, Kacar A, et al. Epidemiology, pathophysiology, clinical evaluation, and treatment of carbon monoxide poisoning in child, infant, and fetus. North Clin Istanb 2017;4(1):100-7.

7. Gasparyan AY, Ayvazyan L, Mikhailidis DP, et al. Mean platelet volume: A link between thrombosis and inflammation? Curr Pharm Des 2011;17(1):47-58.

8. Celik T, Güler E, Atas Berksoy E, et al. Mean platelet volume as a negative marker of inflammation in children with rotavirus gastroenteritis. Iran J Pediatr 2014;24(5):617-22.

9. Oncel MY, Ozdemir R, Yurttutan S et al. Mean platelet volume in neonatal sepsis. J Clin Lab Anal 2012;26(6):493-6.
10. Ozdemir R, Karadeniz C, Doksoz O, et al. Are mean platelet volume and platelet distribution width useful parameters in children with acute rheumatic carditis? Pediatr Cardiol 2014;35(1):53-6.

11. Akbal A, Gokmen F, Gencer M, et al. Mean platelet volume and platelet distribution width can be related to bone mineralization. Osteoporos Int 2014;25(9): 2291-5.

12. Karabacak M, Varol E, Türkdogan $K A$, et al. Mean platelet volume in patients with carbon monoxide poisoning. Angiology 2014;65(3):252-6.

13. Martin JF, Trowbridge EA, Salmon GL, et al. The biological significance of platelet volume: Its relationship to bleeding time, platelet thromboxane B2 production and megakaryocyte nuclear DNA concentration. Thromb Res 1983;32(5):443-60.

14. Jakubowski JA, Thompson CB, Vaillancourt $R$, et al. Arachidonic acid metabolism by platelets of differing size. $\mathrm{Br}$ J Haematol 1983;53(3):503-11.

15. Giles $H$, Smith RE, Martin JF. Platelet glycoprotein IIb-IIla and size are increased in acute myocardial infarction. Eur $\mathrm{J}$ Clin Invest 1994;24(1):69-72.

16. Vij AG. Effect of prolonged stay at high altitude on platelet aggregation and fibrinogen levels. Platelets. 2009;20(6):4217.

17. Mehta SR, Das S, Singh SK. Carbon monoxide poisoning. Med J Armed Forces India 2007;63(4):362-5.

18. Alonso JR, Cardellach F, López $S$, et al. Carbon monoxide specifically inhibits cytochrome $\mathrm{C}$ oxidase of human mitochondrial respiratory chain. Pharmacol Toxicol 2003;93(3):142-6.

19. Goldbaum LR, Orellano T, Dergal E. Mechanism of the toxic action of carbon monoxide. Ann Clin Lab Sci 1976;6(4):3726.

20. Coburn RF, Forman HJ. Handbook of physiology. In: Fishman AP, Farki LE, Geiger SR, eds. Carbon monoxide toxicity. Baltimore: Williams \& Wilkins, 1987:439-56.

21. Piantadosi $C A$, Tatro $L$, Zhang J. Hydroxyl radical production in the brain after CO hypoxia in rats. Free Radic Biol Med 1995;18:603-9.

22. Okeda R, Funata N, Song SJ, et al. Comparative study pathogenesis of selective cerebral lesions in carbon monoxide poisoning and nitrogen hypoxia in cats. Acta. Neuropathol (Berl) 1982;56:265-72.

23. Gilmer B, Kilkenny J, Tomaszewski C, et al. Hyperbaric oxygen does not prevent neurologic sequelae after carbon monoxide poisoning. Acad Emerg Med 2002;9:1-8.

24. Gering SA, Folts JD. Exacerbation of acute platelet thrombus formation in stenosed dog coronary arteries with smoke from a nontobacco burning cigarette. J Lab Clin Med 1990;116(5):728-36.

25. Bierenbaum ML, Fleischman Al, Stier A, et al. Effect of cigarette smoking upon in vivo platelet function in man. Thromb Res 1978;12(6):1051-7.

26. Grace TW, Platt FW. Subacute carbon monoxide poisoning. Another great imitator. JAMA 1981;246(15):1698-700.

27. Aronow WS. Effect of carbon monoxide on cardiovascular disease. Prev Med 1979;8(3):271-8.

28. Varol E, Ozaydin M, Aslan SM, et al. A rare cause of myocardial infarction: Acute carbon monoxide poisoning. Anadolu Kardiyol Derg 2007;7(3):322-3.

29. Hsu PC, Lin TH, Su HM, et al. Acute carbon monoxide poisoning resulting in ST elevation myocardial infarction: $A$ rare case report. Kaohsiung J Med Sci 2010;26(5):271-5. 
30. Ruth-Sahd LA, Zulkosky K, Fetter ME. Carbon monoxide poisoning: Case studies and review. Dimens Crit Care Nurs 2011;30(6):303-14.

31. Felner JM, Churchwell AL, Murphy DA. Right atrial thromboemboli: Clinical, echocardiographic and pathophysiologic manifestations. J Am Coll Cardiol 1984;4(5):1041-51.

32. Marius-Nunez AL. Myocardial infarction with normal coronary arteries after acute exposure to carbon monoxide. Chest 1990; 97(2):491-4.

33. Yildirim C, Gunay N, Buyukaslan H, et al. A case of carbon monoxide poisoning with thrombus in the heart: $\mathrm{A}$ case report. Inhal Toxicol 2005;17(14):797-801.

34. Lee SJ, Kang JH, Kim NY, et al. A case report of carbon monoxide poisoning induced cardiomyopathy complicated with left ventricular thrombus. J Cardiovasc Ultrasound 2011;19(2):83-6
35. Tucciarone M, Arizaca-Dileo $\mathrm{P}$, Rodriguez-Castro E, et al. Myocardial infarction secondary to carbon monoxide poisoning: an uncommon presentation of a common condition. Case report and review of the literature. Am J Ther 2009;16(5):462-5.

36. Tuncel $T$, Uysal $P$, Hocaoglu $A B$, et al. Change of mean platelet volume values in asthmatic children as an inflammatory marker. Allergol Immunopathol (Madr) 2012;40(2):104-7.

37. Wiwanitkit V. Plateletcrit, mean platelet volume, platelet distribution width: Its expected values and correlation with parallel red blood cell parameters. Clin Appl Thromb Hemost 2004;10(2):175-8.

38. Threatte GA. Usefulness of the mean platelet volume. Clin Lab Med 1993;13(4):937-50. 